\title{
GENETIC VARIATION IN RELATIVE CELL INJURY FOR BREEDING UPLAND COTTON UNDER HIGH TEMPERATURE STRESS
}

\author{
Noshair Khan ${ }^{1}$, Irshad Ahmad ${ }^{1}$, Muhammad Tehseen Azhar ${ }^{1 ! *}$ \\ ${ }^{1}$ University of Agriculture, Department of Plant Breeding and Genetics, Faisalabad, PAKISTAN, \\ ' University of Agriculture, Climate Change Chair, U.S. Pakistan Center for Advanced Studies in \\ Agriculture and Food Security, Faisalabad, PAKISTAN, \\ 'The University of Western Australia, School of Plant Biology, AUSTRALIA \\ *Corresponding author: tehseenpbg@uaf.edu.pk
}

Received: 21.03.2016

\begin{abstract}
The objective of present study was to examine the presence of variation in relative cell injury percentage (RCI\%), as a measure of heat tolerance in sample of $G$. hirsutum germplasm and also to investigate genetic basis, if any, of RCI\% under heat stress. For this purpose, response of 70 cotton varieties/lines was studies to optimum and high temperature, and RCI\% was measured at reproductive stage. Data showed differing responses of the germplasm to the two temperature regimes. On the basis of similarities MNH 552, FH 100 and NIAB 111 were screened out as tolerant whilst Cedix ST-362 (GL), LRA 5166 and 4F were identified as susceptible varieties. Three sets of crosses involving tolerant $\times$ susceptible varieties were made according to generation mean technique. Six generations of each cross was field planted under optimum and high temperature and at reproductive stage RCI\% was again measured. Genetic analysis of the data showed the predominant effect of additive component in the inheritance of $\mathrm{RCI} \%$ under both the temperature regimes and consequently estimates of $h^{2}$ ns were high in three crosses. These estimates were used to calculate response to selection in $\mathrm{F}_{3}$ population that appear to be encouraging. The results of present investigation suggest that RCI\% could be used as effective selection criteria for selecting the plants with lower value of RCI\%.
\end{abstract}

Keywords: Generation mean analysis, Gossypium hirsutum L. heat tolerance, relative cell injury, variability

\section{INTRODUCTION}

For best growth and healthy development of cotton crop (Gossypium hirsutum L.), optimum day/night temperature is $30 / 20{ }^{\circ} \mathrm{C}$, with an optimum for photosynthesis being $28{ }^{\circ} \mathrm{C}$ (Burke et al., 1988; Reddy et al., 1997a). Temperature higher than $35^{\circ} \mathrm{C}$ increase photorespiration and impaired reproductive phase seriously causing fruit shedding, pollen sterility and consequently decrease lint yield (Reddy et al., 1991a; Baloch et al., 2000 and Khan et al., 2008). In Pakistan, cotton crop is mostly grown in Sindh and Punjab provinces and in some part of these areas average daily temperature exceeds $35{ }^{\circ} \mathrm{C}$, and reproductive phase is highly sensitive to this temperature and in response to high temperature heavy loss occurs to young fruits i.e. 65 70\% (Taha et al., 1981; Baloch et al., 2000). When temperature decrease during the month of September, 30$35 \%$ of bolls are retained which gives seed cotton yield to the farmers (Taha et al., 1981). It has been reported that high temperature during peak reproductive stage is the basic reason of low yield of cotton in Pakistan (Anonymous, 2005). There is evidence in the literature to how that for every degree of maximum daily temperature over $30^{\circ} \mathrm{C}$ in July decreased lint yield to the extent of 50 $\mathrm{Kg} / \mathrm{hac}$ (Ooesterhuis, 1999), and similarly Bradow and Davidonis (2000) found negative impact of high temperature on fiber quality. Thus there is ample scope for the development of cotton genotypes that are tolerant to high temperature beyond the documented effects on yield and fiber quality. However the use of selection criteria easy to measure heat tolerance of cotton is essential.

Assessment of germplasm at plan maturity particularly reproductive stage under heat stress is effective if relevant and repeatable screening environments are available (Ismail and Hall, 1999). Unfortunately significant, genotype $\times$ year and genotype $\times$ environment effects often hamper genetic advance in the field. Therefore, use of indirect selection criteria for the variation of heat tolerance is advantageous. Relative cell injury \%age which is a measure of cell membrane thermostability (CMT) has been reported as a vital trait of heat tolerance (Blum and Abercon, 1981). This technique was used for the first time by Sullivan (1972) in sorghum for the identification of heat tolerant and sensitive genotypes. RCI had been used by various workers for the identification of temperature sensitive and temperature 
tolerant cotton varieties (Ashraf et al., 1994; Rehman et al., 2004; Azhar et al., 2005, 2009 and Khan et al., 2008). Ashraf et al. (1994) evaluated five varieties of cotton for RCI \% after three weeks of initial growth at $30{ }^{\circ} \mathrm{C}$, and found that MNH 93 with lower relative injury had greater dry mass production than the other three varieties evaluated. In another study, Khan et al. (2008) evaluated 45 varieties for RCI \% which ranged from 44.8 to $79 \%$, and reported NIAB 111 as tolerant variety. In the present study NIAB 111 with minimum injury to cell i.e., $27 \%$ reflected it's greater tolerance to heat. Clearly the present data appeared to agree with that of previous work. Similarly high heat tolerance of MNH 552 has been studied by Rehman et al. (2004) and Azhar et al. (2009), and its superiority has been substantiated in the present studies, whilst $4 \mathrm{~F}$, an old and obsolete cultivar of this region has been found susceptible (Azhar et al., 2009). According to the suggestion of Bibi et al. (2003) that obsolete cultivar suffered more due to heat stress than new one has been substantiated by the data on $4 \mathrm{~F}$ which revealed it's heat susceptibility. Such observations on heat tolerance had been reported in wheat (Galiba et al., 1997; Ibrahim and Quick et al., 2001a and 2001b; Ali et al., 2007), soybean (Martineau et al., 1979a and 1979b), rice (Agari et al., 1995), legumes (Srinavasan et al., 1996), cowpeas (Ismail and Hall, 1999), sorghum (Sullivan and Ross, 1979), tomato (Chen et al., 1982), and the existence of intraspecific variation for heat tolerance reported in various crop species is in agreement with the variation in hirsutum spp. examined here.

The development of heat tolerant plant material through breeding methods requires the existence of genetic variability for heat tolerance within the species. Previous studies revealed ample evidence on the existence of variation in heat tolerance in various crop species for example, wheat (Shanahan et al., 1990; Ibrahim and Quick, 2001a, 2001b), rice (Yoshida et al., 1981; Mackill et al., 1982), cowpeas (Mutters and Hall, 1992; Ahmed et al., 1993ab; El-kholy et al., 1997), tomato (Dane et al., 1991; Abdul-Baki and Stommel, 1995), mung bean (Collins et al., 1995) and cotton (Rehman et al., 2004; Azhar et al., 2009). In the recent years a few studies showed a positive reasonably strong and significant association between CMT and yield (Blum et al., 2001; Rehman et al., 2004). However Rehman et al. (2004) cautioned against using CMT as an indirect selection measure under non-heat stressed environment, concluded that factors other than CMT may influence yield under high temperature, and that CMT alone is not suggested as a selection criteria. Therefore, better understanding of genetic and physiological basis of heat tolerance is essential to develop heat tolerant cotton cultivars. In this paper heat tolerance of $G$. hirsutum L. has been investigated by measuring $\mathrm{RCI} \%$, which is a measure of cellular membrane thermostability. Since no information to-date is available on genetic basis on RCI\% in the literature, and therefore attempt has been made to explain genetic mechanism controlling RCI\%.

In the present work heat tolerance has been studies in upland cotton measuring relative cell injury (RCI) which is a measure of cellular membrane stability (CMT) and has been identified as a vital trait of heat tolerance in crop. RCI level from leaf discs at high temperature has been suggested as a screening tool for heat tolerance in plants (Sullivan, 1972). Although it is dire need, no direct and useful attempts have been made towards understanding genetic, physiological and morphological basis of heat tolerance in Pakistan.

Keeping in view the importance of cotton crop in the buildup of the economy of Pakistan, development of tolerance against high temperature would be of a value both to the farmers and the country. Earlier information about the presence of variation for heat tolerance is very scanty, and what does exist in the literature revealed that variability within species is available (Trolinder and Shang, 1991; Baloch and Lakho, 2000; Rahman et al., 2004; Azhar et al., 2009). In addition, from the studies of intergeneric differences in heat tolerance (Srinavasan et al., 1996) it is clear that potential for selection and breeding for enhanced heat tolerance is existing.

\section{MATERIALS AND METHODS}

The plant material for the study of variation in relative cell injury (RCI\%) in G. hirsutum L. and its genetic controlling mechanisms were studied in the Department of Plant Breeding and Genetics, University of Agriculture, Faisalabad (Pakistan) during 2012-2015. The cotton germplasm was sown under heat stress. Name of each genetic entry examined for RCI\% is given in Table 1.

\section{Evaluation of germplasm for RCI}

The 70 varieties were grown in pots measuring $30 \mathrm{~cm}$ height and $30 \mathrm{~cm}$ diameter paced under optimum (to be called normal temperature, day/night) at 31-34/19-21 \pm $2{ }^{\circ} \mathrm{C}$ and higher temperature (heat stress), $42-44^{\circ} \mathrm{C} / 24-$ $27 \pm 2^{\circ} \mathrm{C}$. The two temperatures were developed in two separate growth chambers in glass house. In one chamber optimal temperature was maintained and in other temperature was gradually increased to obtain desired degree of the temperature, till the start of the reproductive stage. 
Table 1. RCI\% of 70 varieties of Gossypium hirsutum L. grown under two temperature regimes

\begin{tabular}{|c|c|c|c|}
\hline Code No & Varieties & Optimum & High \\
\hline 1 & Greg $25 \mathrm{~V}$ & 45.0 & 53.3 \\
\hline 2 & Royal S. Okra & 69.7 & 81.0 \\
\hline 3 & YEP5 & 63.3 & 72.3 \\
\hline 4 & Coker 310 & 61.0 & 69.7 \\
\hline 5 & Linea 100 & 57.0 & 67.3 \\
\hline 6 & Barb XL1 & 58.7 & 69.0 \\
\hline 7 & LRA5166 & 74.3 & 95.0 \\
\hline 8 & Acala1517C & 55.0 & 62.3 \\
\hline 9 & Riba 50 & 52.0 & 59.3 \\
\hline 10 & TH 4183 & 50.7 & 58.0 \\
\hline 11 & Frego & 50.3 & 57.3 \\
\hline 12 & DPL2775 & 50.0 & 57.3 \\
\hline 13 & DPL61 & 49.3 & 56.0 \\
\hline 14 & Cedix St 362 (GL) & 74.0 & 94.7 \\
\hline 15 & GFS & 36.0 & 44.0 \\
\hline 16 & $\mathrm{CP} / 15 / 2$ & 45.3 & 55.3 \\
\hline 17 & Tidewater & 48.0 & 57.3 \\
\hline 18 & $4 \mathrm{~F}$ & 73.0 & 93.7 \\
\hline 19 & SLH41 & 65.7 & 77.7 \\
\hline 20 & PB899 & 54.3 & 67.7 \\
\hline 21 & PB900 & 52.7 & 66.3 \\
\hline 22 & VH144 & 43.7 & 53.7 \\
\hline 23 & FH1000 & 27.0 & 29.3 \\
\hline 24 & FH900 & 70.7 & 83.0 \\
\hline 25 & AC134 & 52.0 & 61.3 \\
\hline 26 & CIM 443 & 64.3 & 77.0 \\
\hline 27 & MNH424 & 51.3 & 62.7 \\
\hline 28 & MNH129 & 78.0 & 88.0 \\
\hline 29 & MNH440 & 46.0 & 55.7 \\
\hline 30 & MNH394 & 43.7 & 54.3 \\
\hline 31 & NIBGE3701 & 53.3 & 62.0 \\
\hline 32 & MNH552 & 26.0 & 28.3 \\
\hline 33 & MNH786 & 43.0 & 50.3 \\
\hline 34 & MNH789 & 48.0 & 57.0 \\
\hline 35 & MNH633 & 59.7 & 66.3 \\
\hline 36 & MNH706 & 53.3 & 64.0 \\
\hline 37 & MNH765 & 40.7 & 50.3 \\
\hline 38 & MNH738 & 47.0 & 58.3 \\
\hline 39 & $\mathrm{~S} 12$ & 71.3 & 84.0 \\
\hline 40 & FH 114 & 46.0 & 56.0 \\
\hline 41 & NIBGE1524 & 47.3 & 57.3 \\
\hline 42 & NIBGE601 & 44.7 & 53.7 \\
\hline 43 & CRISS403 & 56.7 & 66.0 \\
\hline 44 & CRISS134 & 47.3 & 58.0 \\
\hline 45 & CIM446 & 71.0 & 84.7 \\
\hline 46 & CIM448 & 58.7 & 71.3 \\
\hline 47 & CIM1100 & 41.3 & 47.7 \\
\hline 48 & CIM473 & 43.0 & 50.3 \\
\hline 49 & CIM240 & 70.7 & 83.7 \\
\hline 50 & CIM511 & 57.0 & 68.3 \\
\hline 51 & CIM557 & 39.7 & 49.3 \\
\hline 52 & CIM541 & 41.7 & 49.7 \\
\hline 53 & CIM554 & 53.0 & 66.7 \\
\hline 54 & BH118 & 68.7 & 79.0 \\
\hline 55 & BH126 & 41.0 & 51.3 \\
\hline 56 & BH121 & 45.7 & 55.7 \\
\hline 57 & BH160 & 54.7 & 65.3 \\
\hline 58 & BH162 & 32.3 & 37.7 \\
\hline 59 & NIAB 111 & 25.0 & 27.3 \\
\hline 60 & NIAB KARISHMA & 47.7 & 59.0 \\
\hline 61 & NIAB 78 & 52.3 & 64.3 \\
\hline 62 & B557 & 35.0 & 44.0 \\
\hline 63 & NIAB 884 & 53.3 & 60.3 \\
\hline 64 & NIAB 999 & 44.0 & 52.7 \\
\hline 65 & FH 113 & 59.0 & 68.0 \\
\hline 66 & CIM 499 & 74.3 & 88.3 \\
\hline 67 & BH147 & 74.7 & 88.3 \\
\hline 68 & VH142 & 79.0 & 91.3 \\
\hline 69 & MNH 93 & 73.7 & 86.7 \\
\hline \multirow[t]{2}{*}{70} & CIM707 & 72.3 & 87.0 \\
\hline & $\mathrm{Cd} 5 \%$ & 2.54 & 2.08 \\
\hline
\end{tabular}

These pots were filled with $9 \mathrm{~kg}$ pre-tested field soil. Components of soil testing were $\mathrm{pH}(8.1), \mathrm{EC}(1.2 \mathrm{dS} / \mathrm{m})$, organic matter $(1.42 \%)$, saturation percentage $(31 \%)$, phosphorous (28.9 ppm) and potassium (135 ppm). The seeds of 70 varieties were soaked for eight hours, and four seeds of each genetic entry were sown in each pot during October, 2012, and were thinned to one seedling at two true leaf stage. There were 5 pots of each genetic entry in one replication, thus having 15 plants in three replications. In total there were 1050 plants in each temperature regime, and these were arranged according to completely randomized design. In both the chambers day length was 14 hours, natural light (PAR ranged 1400-1600 $\mu \mathrm{mol} \mathrm{nf}^{2} \mathrm{~s}$ at noon) and 65-80 \% humidity. The earthen ports were supplied with normal irrigation water at the rate of 1400 $\mathrm{ml}$ per pot daily during peak flowering period, and afterwards on alternate days. All other growing conditions were kept uniform, till maximum flush of flowers was noted on stress and non-stress plants.

For measuring RCI \% of 70 varieties, leaves were tagged on the day they unfolded, and that was designated as day 1 . A steel punch of $10 \mathrm{~mm}$ inner diameter was used for punching leaf discs. Samples were collected in paired sets from both sides of central rib of a leaf for heat stressed (high temperature) and non-heat stressed (normal). Leaf discs were excised between 1300 and 1500 hour, and were immediately placed in glass vials containing $2 \mathrm{ml}$ deionized water. Vials were brought to the laboratory quickly. Leaf discs were thoroughly rinsed thrice with deionized water to wash out electrolyte adhered on the surface or those already released into water. After final washing, $2 \mathrm{ml}$ deionized water was added to each vial and capped to avoid desiccation and evaporation during heat treatment. One set of vials was treated at $50^{\circ} \mathrm{C}$ for 1 hour in water bath, whilst other set was kept at $25^{\circ} \mathrm{C}$ for one hour. After heat treatment, $10 \mathrm{ml}$ deionized water was added to each vial and held at $10{ }^{\circ} \mathrm{C}$ for 24 hours to allow diffusion of electrolytes. Vials were brought to $25^{\circ} \mathrm{C}$ and shaked to mix the contents. Initial reading was taken using EC meter (Model, 1-11-933300, Harina Instrument, USA). Vials were autoclaved for 10 minutes at $0.10 \mathrm{MPa}$ pressure to kill the tissues and release of all the electrolytes. Vials were again brought to $25^{\circ} \mathrm{C}$ and final EC reading was measured. Relative cell injury percentage ( $\mathrm{RC} 1 \%)$, an indicator of cell membrane thermostability (CMT), was calculated using following function (Sullivan, 1972).

$$
\operatorname{RCI}(\%)=\left[1-\left[\left\{1-\left(\mathrm{T}_{1} / \mathrm{T}_{2}\right)\right\} /\left\{1-\left(\mathrm{C}_{1} / \mathrm{C}_{2}\right)\right\}\right]\right] \times 100
$$

Where, $\mathrm{T}$ and $\mathrm{C}$ denote $\mathrm{EC}$ of heat treated and controlled vials, and subscripts I and 2 denote initial and final EC readings, respectively.

\section{Assessment of heat tolerance}

The absolute of RCI\% of 70 varieties were used to evaluate variation in the cotton germplasm. Many workers (Azhar et al., 2003; Akhtar et al., 2008; Iqbal et al., 2011) have found this method useful to distinguish tolerant and susceptible varieties of cotton under drought and heat stress. 


\section{Development of plant material for genetic studies}

Comparison of $\mathrm{RCI} \%$ of 70 varieties revealed the three varieties namely MNH 552, FH 1000 and NIAB 111 had low $\mathrm{RCI} \%$, and therefore were found to be heat tolerant, and in contrast Cedix ST-362, LRA 5166 and 4F with higher values of RCI\% were identified as heat susceptible. The six varieties were sown in earthen pots placed in glasshouse during October 2013. Three sets of crosses i.e., MNH-552 × Cedix ST-362 (GL), FH-1000 × LRA 5166 and NIAB- $111 \times 4 \mathrm{~F}$, were attempted in glasshouse, these will be referred as to, Cross-1, Cross-2 and Cross-3 respectively.

Half quantity of the $F_{1}$ seed was stored and other half and their parents were planted during normal crop season, May-June 2014. When $F_{1}$ plants started to flower, these were crossed back with their respective parents to develop seeds of backcross $1 \quad\left(\mathrm{BC}_{1}\right)$, backcross $2\left(\mathrm{BC}_{2}\right)$ and backcross $3\left(\mathrm{BC}_{3}\right)$ whilst some of the $\mathrm{F}_{1}$ plants were also selfed to obtain $\mathrm{F}_{2}$ seed. At maturity seed cotton of these genotypes was collected and ginned.

\section{Evaluation of plant material for RCI at plant maturity}

Since development of these two temperature regimes in the field is very difficult and uncertain and therefore growing of plants under normal and high temperature in the field is not practicable, however this difficulty may be overcome by planting plant material at different sowing dates as had been done in Brassica (Morrison and Stewart, 2002), this method followed by many works and this method had been presently in cotton (Steiner and Jacobsen, 1992; Rahman et al., 2004; Azhar et al., 2009). For the assessment of different genotypes, seeds of six generations i.e. $\mathrm{P}_{1}, \mathrm{P}_{2}, \mathrm{~F}_{1}, \mathrm{~F}_{2}, \mathrm{BC}_{1}, \mathrm{BC}_{2}$ were sown in the field during 2015, during early April (for high temperature), and early June (normal temperature). A triplicated randomized complete block design was followed for the conductance of this experiment. Each genetic entry was planted in a single row plot of $450 \mathrm{~cm}$ long having 16 plants spaced $30 \mathrm{~cm}$ apart within the row and $75 \mathrm{~cm}$ between the rows. There was one row of each $\mathrm{P}_{1}, \mathrm{P}_{2}$ and $\mathrm{F}_{1}$, three rows of $\mathrm{BC}_{1}$ and $\mathrm{BC}_{2}$ and six rows of $\mathrm{F}_{2}$ of each genetic entry in one replication for two seeds of each entry were dibbled 5-6 cm deep per hill, and when seedling were $15 \mathrm{~cm}$ high, they thinned to one seedling. The plants were sprayed with suitable as and when needed to obtain clean plants. Both the experiments were conducted on the same piece of land to minimize possible soil heterogeneity. Adequate irrigation was applied when needed. All general production practices recommended for cotton crop were adopted identically for both the experiments. During the development and maturity of plants in six generations, data on the following characters were measured.

\section{Statistical analysis}

Absolute and relative data (indices of heat tolerance) on canopy temperature of 70 cotton varieties were analyzed following ordinary analysis of variance technique (Steel et al., 1997) to see whether the genotypic differences were significant. For genetic analysis coefficients for partitioning of the six generations were made according to Little and Hills (1978). The genetic basis of variation in heat tolerance was investigated following the approach of generation means analysis (Mather and Jinks, 1982). Means and variances of two parents, $\mathrm{F}_{1}, \mathrm{~F}_{2}, \mathrm{BC}_{1}$ and $\mathrm{BC}_{2}$ were calculated. A weighted least square analysis was performed on generation means commencing from the simplest model using parameter ' $\mathrm{m}$ ' only. Further models of increasing complexity "md", "mdh", etc. were fitted if sum of squares were significant. The best fit model was the one which had significant estimates along with non-significant Chi square value.

\section{RESULTS}

Mean squares of RCI\% of 70 varieties of $G$. hirsutum L. grown in optimum and high temperature were obtained from simple analysis of variance technique. Mean squares of 70 varieties were highly significant $(\mathrm{P} \leq 0.01)(\mathrm{ms}=$ 1234.36) and these varieties responded differently to two temperature regimes as the mean squares were highly significant $(\mathrm{P} \leq 0.01)(\mathrm{ms}=17.99)$ and the two temperatures also differed significantly $(\mathrm{P} \leq 0.01)(\mathrm{ms}=$ 10934.40) (table is not given).

Comparison of RCI\% of 70 varieties differed appreciably even under controlled temperature (Table 1), however, RCI measured under high temperature, minimum injury to cells i.e. $27 \%, 28 \%$, and $29 \%$ was found in NIAB111 (No. 59), MNH552 (No.32) and FH 1000 (No.23) respectively, and were revealed to be more tolerant than any of the other variety assessed. By contrast, greater injury occurred in AC134 (No.25, 61\%), NIAB 78 (No.61, 64\%), BH126 (No.55, 51\%), PB899 (No.20, 68\%), DPL-2775 (No.12, 57\%), CIM554 (No.53, 67\%), CIM446 (No.45, 85\%) and BH147 (No.67, 87\%) and revealed essentially similar heat tolerance, and may be regarded as intermediate group under heat stress, cells of varieties of 4F (N. 18), Cedix ST. 362 (GL) (No. 4) and LRA 5166 (No. 7) were seriously injured to the extent of $93.77 \%, 94.7 \%$ and $95 \%$, and these varieties may be called highly sensitive varieties.

Six generations i.e. $\mathrm{P}_{1}, \mathrm{P}_{2}, \mathrm{~F}_{1}, \mathrm{~F}_{2}, \mathrm{BC}_{1}$ and $\mathrm{BC}_{2}$ of each of the three crosses i.e. Cross -1 , Cross -2 and Cross -3 were grown in the field during April (high temperature) and early June (normal temperature) as has been done in Brassica (Morrison and Stewart, 2002) and cotton (Akhter et al., 2008). At plant maturity, data on RCI\% were collected, and assessment of the genotypic responses to high temperature was compared with that of control. Absolute data regarding RCI\% in each of the three crosses under consideration measured in control and high temperature were subjected to ordinary analysis of variance technique (Steel et al., 1997). The study of the mean squares revealed highly significant differences $(\mathrm{P} \leq$ 0.001 ) between the generations of three crosses (Table 2). Significant mean squares $(\mathrm{P} \leq 0.001)$ due to high temperature indicated that temperature during April and June was also different, and the varieties responded differently to the two stress conditions. The data of means 
of $\mathrm{RCI} \%$ of these six generation and $\mathrm{h}^{2}{ }_{\mathrm{ns}}$ of three crosses is mentioned in also presented herein. The $\mathrm{h}^{2}{ }_{\mathrm{ns}}$ of three crossed grown in optimum conditions was found to be moderate to high (65 to $80 \%$ ), while it was $93 \%$ existed for populations grown in high temperature (|Table 3).

Table 2. Mean squares due to absolute data for RCI\% in three Crosses of Gossypium hirsutum L.

\begin{tabular}{|c|c|c|c|c|}
\hline Sources of Variation & D.F. & Crosse-1 & Cross-2 & Cross-3 \\
\hline Replications & 2 & 23.4 & 3175.6 & 95.6 \\
\hline Generations (G) & 5 & $28581.30 * *$ & $33211.30 * *$ & $25633.80 * *$ \\
\hline Temperature (T) & 1 & $7280.20 * *$ & $876.80^{*}$ & $6617.90 * *$ \\
\hline $\mathbf{G} \times \mathbf{T}$ & 5 & $31.60^{\mathrm{ns}}$ & $1119.90 * *$ & $26.00^{\mathrm{ns}}$ \\
\hline Error & 1336 & 131.3 & 165.5 & 129.9 \\
\hline
\end{tabular}

Table 3. Means of six generations and heritability $\left(\mathrm{h}^{2}{ }_{\mathrm{ns}}\right)$ of RCI\% in three crosses of Gossypium hirsutum L. grown under two temperature regimes

\begin{tabular}{cccccccc}
\hline \multirow{2}{*}{ Generations } & $\begin{array}{c}\text { Cross- 1 } \\
\text { Optimum }\end{array}$ & High & $\begin{array}{c}\text { Cross-2 } \\
\text { Optimum }\end{array}$ & High & Cross-3 & Optimum & High \\
\hline $\mathbf{P}_{1}$ & 25.80 & 28.78 & 24.98 & 27.98 & 24.51 & 29.24 \\
$\mathbf{P}_{2}$ & 68.44 & 74.33 & 71.98 & 77.91 & 67.20 & 72.47 \\
$\mathbf{F}_{1}$ & 47.58 & 51.64 & 48.09 & 53.18 & 47.16 & 50.49 \\
$\mathbf{F}_{2}$ & 47.98 & 53.13 & 48.55 & 45.24 & 45.34 & 49.87 \\
$\mathbf{B C}_{1}$ & 37.31 & 41.79 & 37.41 & 41.88 & 36.48 & 41.59 \\
$\mathbf{B C}_{2}$ & 57.67 & 61.81 & 57.39 & 62.93 & 55.51 & 59.05 \\
$\mathbf{h}^{2}$ ns & 0.65 & 0.91 & 0.73 & 0.90 & 0.80 & 0.93 \\
\hline
\end{tabular}

Due to the presence of non-significant Chi square value, various genetic models are fitted on inheritance of RCI\% in three populations. Three parameter models "mdh" was best fit for cross- 1 and 2 while five parameter models "mdhij" was best fit for cross-3 grown in optimum conditions (Table 4). High values of "d" as compared to " $h$ " revealed that inheritance of $\mathrm{RCI} \%$ is governed by additive effects if three these crosses are grown in optimum conditions. The presence of " $i$ and $j$ " for cross- 3 indicated that inheritance $\mathrm{RCI} \%$ in cross-3 is also influenced by interaction of Additive $\times$ Additive and Additive $\times$ Dominant effects respectively. In contrast, two parameters (md) model was best fit for cross-1 grown in high temperature, but six parameter model (mdhijl) was fit for cross-2 and 3 . The values of " $d$ " and " $h$ " indicated that additive effects were involved in the inheritance of RCI\% in cross- 1 and 3 while dominant genes were responsible in cross-2. In addition, epistatic effects were observed in inheritance of RCI\% in Cross-2 and Cross-3. These effects can be seen due to the presence of opposite signs (+ and -) in " $\mathrm{i}$ " and " $\mathrm{l}$ " in generation mean analysis of certain traits. The collected data on RCI\% was also analyzed for component of variance namely, additive (D), dominance $(\mathrm{H})$, environments $(\mathrm{E})$ and interaction $(\mathrm{F})$ (Table 5). This analysis revealed the contribution of $\mathrm{D}$ in the inheritance of RCI under optimum and high temperature; however $\mathrm{H}$ also contributed in case of Cross- 1 and Cross- 2 under optimum conditions. Effects of interactions (F) were also noted in the inheritance of RCI in Cross-2 grown under optimum conditions.

Table 4. Components of generation means, m, [d], [h], [i], [j] and [1] for RCI \% in three crosses of Gossypium hirsutum L. grown under two temperature regimes

\begin{tabular}{|c|c|c|c|c|c|c|c|c|c|}
\hline \multicolumn{10}{|c|}{ Optimum } \\
\hline Crosses & m & [d] & {$[\mathrm{h}]$} & [i] & {$[\mathrm{j}]$} & [I] & $\chi^{2}$ & DF & Probability \\
\hline Cross -1 & $47.13 \pm 0.067$ & $21.31 \pm 0.067$ & $0.45 \pm 0.10$ & & & & 1.7641 & 3 & $0.90-0.100$ \\
\hline Cross -2 & $48.45 \pm 0.14$ & $23.47 \pm 0.14$ & $-0.39 \pm 0.22$ & & & & 6.4889 & 3 & $0.100-0.050$ \\
\hline Cross -3 & $43.61 \pm 0.75$ & $21.35 \pm 0.14$ & $3.54 \pm 0.85$ & $2.24 \pm 0.78$ & $-4.64 \pm 1.29$ & & 0.0367 & 1 & $.0 .90-0.100$ \\
\hline \multicolumn{10}{|c|}{ High } \\
\hline Cross -1 & $51.58 \pm 0.08$ & $22.77 \pm 0.09$ & & & & & 6.6625 & 4 & $0.90-0.100$ \\
\hline Cross -2 & $24.32 \pm 4.28$ & $24.96 \pm 0.15$ & $84.84 \pm 8.61$ & $28.62 \pm 4.27$ & $-2.95 \pm 0.47$ & $-25.99 \pm 4.35$ & 0.0000 & 0 & Significant \\
\hline Cross -3 & $59.59 \pm 3.81$ & $21.61 \pm 0.12$ & $-29.81 \pm 7.68$ & $-8.74 \pm 3.81$ & $-7.40 \pm 0.44$ & $20.70 \pm 3.90$ & 0.0000 & 0 & Significant \\
\hline
\end{tabular}

Cross 2-Dominance, duplicate dominance

Cross 3-Additive, duplicate dominance 
Table 5. Components of variance for RCI \% in three crosses of Gossypium hirsutum L. grown under two temperature regimes

\begin{tabular}{|c|c|c|c|c|c|c|c|}
\hline \multicolumn{8}{|c|}{ Optimum } \\
\hline Crosses & D addit & H dominat & F interaction & E envi & $\chi^{2}$ & D.F & Probability \\
\hline Cross -1 & $687.84 \pm 78.25$ & $-489.92 \pm 83.69$ & & $0.33 \pm 0.04$ & 1.6640 & 3 & $0.90-0.100$ \\
\hline Cross -2 & $916.02 \pm 109.95$ & $-620.24 \pm 123.84$ & $-100.43 \pm 16.41$ & $1.86 \pm$ & 0.23 & 2 & $0.90-0.100$ \\
\hline Cross $\mathbf{- 3}$ & $96.76 \pm 6.26$ & & & $1.84 \pm 0.22$ & 0.7090 & 4 & $0.975-0.950$ \\
\hline \multicolumn{8}{|c|}{ High } \\
\hline Cross -1 & $512.64 \pm 31.35$ & & & $0.83 \pm 0.10$ & 8.078 & 4 & $0.100-0.050$ \\
\hline Cross -2 & $626.58 \pm 38.42$ & & & $1.54 \pm 0.19$ & 5.4231 & 4 & $0.90-0.100$ \\
\hline Cross -3 & $494.12 \pm 30.44$ & & & $1.98 \pm 0.24$ & 3.0864 & 4 & $0.90-0.100$ \\
\hline
\end{tabular}

\section{DISCUSSION}

In the present investigations, assessment of variation in heat tolerance based upon RCI was made at the commencement of reproductive stage. The data on RCI\% suggest that there is considerable variability in heat tolerance in G. hirsutum L. The absolute measures of heat tolerance allowed the identification of highly tolerance, highly susceptible and medium tolerant groups. Similarly total number of varieties examined for RCI reveals general patterns of responses to optimum and high temperature showing a diverse range in responses to heat. Clearly the present data suggest that workable variability for heat tolerance is available in the material and may be exploited through selection and breeding.

The expression of heat tolerance in crop species is a complex phenomenon; both genetic and environmental factors are involved in the manifestation of heat tolerance (Bibi et al., 2003). In the current study data on RCI \% was used to investigate genetic mechanism controlling RCI\% in Gossypium hirsutum L. following generation mean analysis (Mather and Jinks, 1982). Generation means analysis revealed additive [d] and non-additive $[\mathrm{h}]$ gene effects in RCI under optimum and high temperature, except in Cross-1 under high temperature (Table 4). The negative value of $[\mathrm{h}]$ indicated that dominance is directional towards lower parent, and this information is useful for lowering RCI \% in selected plants.

The presence of additive $\times$ additive [i] interaction was evidenced in the inheritance of $\mathrm{RCI} \%$ in cross 3 under optimum temperature, and Cross-2 and Cross-3 under high temperature and this epistatic component suggests that fixation of additive alleles is possible in later generation (Singh et al., 2000; Ali et al,. 2004). Genetic mechanism controlling RCI\% appeared to be complicated by additive $\times$ dominance [j] in Cross-3 under optimum and Cross- 2 and Cross- 3 under high temperature and dominance $\times$ dominance [1] interactions in Cross-2 and Cross-3 and these epistatic components warrants the breeders to be careful while looking for plants having lower $\mathrm{RCI} \%$ and for that matter heat tolerant plants in segregating generations

Genetic variance analysis has been widely adopted by the research workers to partition the total variance into additive (D), dominance (H), environments (E) and interaction (F). In the present study inheritance of RCI\% was affected by D (additive) component under optimum and high temperature, however under optimum temperature dominance component $(\mathrm{H})$ in Cross 1 and
Cross-2 also appeared to be important (Table 5). Similarly, presence of $\mathrm{F}$ component complicated the inheritance of $\mathrm{RCI} \%$ in Cross-2 under optimum temperature. These results indicated that both additive and non-additive variance was important for the genetic control of RCI\%, however pronounced effect of "D" component indicated the dispersion of positive and negative alleles in the two parents. There is no information reported to support the present finding, however Randhawa et al. (1986), Kohel (1987) and Rahman and Malik (2008) observed additive component in the genetic variation of different plant traits of $G$. hirsutum L.. The presence of non-allelic interaction due to [i], [j], [1] observed in generation means analysis has not been detected through generation variance, and therefore suggestion of Malik et al. (1999), Shakoor et al. (2010) and Sarwar et al. (2012) was substantiated here.

Estimates of narrow sense heritability for $\mathrm{RCI} \%$ appeared to be little inflated under high temperature (Table 3), whilst these were low under optimum temperature. The higher estimates of heritability might be due to better additive genetic dissimilarity due to appearance of genes related to stress tolerance or other environmental variation (Saranga et al., 1992). It has been suggested that hidden variation could be exposed due to moderate stress, and thus presenting the chance of increasing heritability estimates in plants (Bradshaw and Hardwick, 1989). Low and high estimates of $h^{2} n$ in cotton had been reported for various plant characters (Ulloa, 2006; Shakoor et al, 2010; Saravanam et al., 2003; Ahuja 2004; Irshad et al., 2012). These estimates of $h^{2} n$ appeared to be inspiring to cotton breeders, suggesting that selection of plants with lower degree of RCI\%, and thereby enhanced heat tolerance in progenies is possible at the time of maturity. However, Falconer and Mackey (1996) had suggested that the estimates are subject to environmental variation, and therefore before making selection these estimates must be substantiated under differing temperature regimes.

The estimates of $h^{2} n s$ may be used to predict response to selection (R) which is equal to the product of $h^{2} n s \times S \bar{d}$ (is difference between the mean of original $\mathrm{F}_{2}$ population and the mean of the selected $\mathrm{F}_{3}$ population). For example, the values of the response, $\mathrm{R}$ for the plant material under high temperature is 13.3, 12.17 and 11.47 in Corss-1, Cross- 2 and Cross- 3 and the mean of $\overline{\mathrm{X}}_{\mathrm{F}_{3}}$ is $40.01,33.07$ and 38.40 respectively (Table 6). This revealed that progeny from $\mathrm{F}_{2}$ population will have decrease amount of 
$\mathrm{RCI} \%$ in $\mathrm{F}_{3}$ population, which will lead to the increase in heat tolerance. This genetic gain seems to be encouraging for the plant material. In previous studies significant increases over original population due to high estimates of $\mathrm{h}^{2} \mathrm{~ns}$ had been made in Medicago sativa L. (Dobrenz et al., 1981; Noble et.al., 1984). Due to the genetic basis of salt tolerance improvement in seven grass and four forage species (Ashraf et al., 1987) and wheat (Ali et al., 2004) had also been reported.

Table 6. Response to selection for RCI\% in three crosses of Gossypium hirsutum L. grown under high temperature

\begin{tabular}{lccc}
\hline & Cross 1 & Cross 2 & Cross 3 \\
\hline$\overline{\mathrm{X}}_{0} \mathrm{~F}_{2}$ & 53.3 & 45.24 & 49.87 \\
$\overline{\mathrm{X}}_{\mathrm{S}} \mathrm{F}_{2}$ & 38.81 & 31.72 & 37.53 \\
$\mathrm{~S} \overline{\mathrm{d}}$ & 14.32 & 13.52 & 12.34 \\
Response $=\mathrm{S} \overline{\mathrm{d}} \times \mathrm{h}^{2}{ }_{\mathrm{n}}$ & 13.3 & 12.17 & 11.47 \\
$\overline{\mathrm{X}}_{\mathrm{F}_{3}}$ & 40.01 & 33.07 & 38.40
\end{tabular}

$\overline{\mathrm{X}}_{0}$ : mean of original segregating population; $\overline{\mathrm{X}}_{\mathrm{S}}$, mean of plants selected for the population; $\mathrm{R}$, response to selection; $\overline{\mathrm{X}}_{\mathrm{F}_{3}}$, expected mean of next segregating population.

Comparison of the three crosses for genetic gains in physiological and agronomic characters, Cross-2 (FH1000 $\times$ LRA5166), exhibited its genetic potential for heat tolerance, and thus may be exploited through selection and breeding. The information reported herein cannot be generalized for whole of germplasm of upland cotton and all the cotton growing areas in Pakistan. Therefore another study involving different germplasm may be conducted to substantiate the information reported herein. However, the knowledge obtained from the present study may be of some value to the cotton breeders working in the cotton belt of Pakistan.

\section{LITERATURE CITED}

Abdul-Baki, A.A. and J.R. Stommel. 1995. Pollen viability and fruit set of tomato genotypes under optimum and hightemperature regimes. Hort. Sci. 30: 115-117.

Agari, S., N. Hanaoka, F. Kubota, W. Agata and P.B. Kaufman. 1995. Measurement of cell membrane stability evaluated by electrolyte leakage as a drought and heat tolerance test in rice (Oryza sativa L.). J. Agric. Kyushu Univ. 40: 233-240.

Ahmed, F.E., A.E. Hall and M.A. Madore. 1993a. Interactive effects of high temperature and elevated carbon dioxide concentration on cowpea [Vigna unguiculata (L.) Walp.]. Plant Cell Environ. 16: 835-842.

Ahmed, F.E., R.G. Mutters and A.E. Hall. 1993b. Interactive effects of high temperature and light quality on floral bud development in cowpea. Functional Plant Biol. 20: 661-667.

Ahuja, S.L., D. Monga, O.P.Tuteja, S.K. Verma, L.S. Dhayal and Y. Dutt. 2004. Association in path analysis in the selections made from color linted Ghossypium hirsutum L. cotton germplasm. J. Cotton Res. Development 18: 137-140.

Akhtar, M.M., F.M., Azhar and Z. Ali. 2008. Genetic basis of fiber quality attributes in upland cotton (Gossypium hirsutum) germplasm. Int. J. Agric. Biol. 10: 217-220.

Ali, Z. 2004. Genetic basis of salt tolerance in wheat (Doctoral dissertation, Ph. D. Dissertation. University of Agriculture Faisalabad Pakistan.
Ali, Z., A. Salam, F.M. Azhar and I.A. Khan. 2007. Genotypic variation in salinity tolerance among spring and winter wheat (Triticum aestivum L.) accessions. S. Afr. J. Bot. 73: 70-75.

Anonymous. 2005. Economic survey of Pakistan 2004-2005, Govt. of Pakistan, Finance Division, Economic Advisor's Wing, Islamabad.

Ashraf, M., M.M. Saeed and M.J. Qureshi. 1994. Tolerance to high temperature in cotton at initial growth stages. Environ. Exp. Bot. 343, 275-283.

Ashraf, M., T. McNeilly and A.D. Bradshaw, 1987. Selection and heritability of tolerance to sodium chloride in four forage species. Crop Sci. 27: 232-234.

Azhar, F.M., Z. Ali, M.M. Akhtar, A.A. Khan and R. Trethowan. 2009. Genetic variability of heat tolerance, and its effect on yield and fiber quality traits in upland cotton (Gossypium hirsutum L.). Plant Breeding 128: 356-362.

Azhar, F.M., Z. Ali, M.M. Akhtar, A.A. Khan and R. Trethowan. 2009. Genetic variability of heat tolerance, and its effect on yield and fiber quality traits in upland cotton (Gossypium hirsutum L.). Plant Breeding 128: 356-362.

Azhar, M.T. 2003. Genetics of heat tolerance and other agronomic characters of Gossypium hirsutum L. M.Sc. (Hons) Agri. Thesis. Dept. Plant Breed, Genet., Univ. Agri. Faisalabad.

Azhar, M.T., A. A. Khan and I. A. Khan. 2005. Combining ability analysis of heat tolerance in Gossypium hirsutum L. Czech J. Genet. Plant Breed. 41: 23-28.

Baloch, M. S., I.U. Awan, S. A. Jatoi, I. Hussain and B. U. Khan. 2000. Evaluation of seeding densities in broadcast wet seeded rice. J. Pure and Applied Sci. 19: 63-65.

Baloch, M.J. and A.R. Lakho. 2000. Screening of cotton genotypes for heat tolerance via in vitro gametophytic selection technique. Pak. J. Biol. Sci. 3:2037-2038.

Baloch, M.J., A.R. Lakho, R. Rind and H. Bhutto. 2000. Screening of cotton genotypes for heat tolerance via in vitro gametophytic selection technique. Pak. J. Biol. Sci. 3:20372038.

Bibi, A.C., D.M. Oostterhuis, R.S. Brown, E.D. Gonias and F.M. Bourland. 2003. The physiological response of cotton to high temperatures for Germplasm screening. Summaries of Arkansas Cotton Research Series 521:87-93.

Blum, A. and A. Ebercon. 1981. Cell membrane stability as a measure of drought and heat tolerance in wheat. Crop Sci. 21:49-47.

Blum, A., N. Klueva and H. T. Nguyen. 2001. Wheat cellular thermotolerance is related to yield under heat stress. Euphytica 117: 117-123

Bradow, J.M. and G.H. Davidonis. 2000. Quantitation of fiber quality and the cotton production-processing interface: A physiologist's perspective. J. Cotton Sci. 4: 34-64.

Bradshaw, A.D. and K. Hardwick. 1989. Evolution and stressGenotypic and phenotypic components. Biol. J. Linnean Soc. 37: 137-155.

Burke, J.J., J.R. Mahan and J.L. Hatfield. 1988. Crop-specific thermal kinetic windows in relation to wheat and cotton biomass production. Agron. J. 80: 553-556.

Chen, RH., Z.Y. Shen and P.H. Li. 1982. Adaptability of crop plants to high temperature stress. Crop Sci. 22: 719-725.

Collins, G.G., X.L. Nie and M.E. Saltveit. 1995. Heat shock proteins and chilling sensitivity of mung bean hypocotyls. J. Exp. Bot. 46:795-802.

Dane, F., A.G. Hunter and O.L. Chambliss. 1991. Fruit set, pollen fertility, and combining ability of selected tomato genotypes under high-temperature field conditions. J. Am. Soc. Hortic. Sci. 116: 906-910.

Dobrenz, A.K., J.E. Stone and M.H. Schonhorst. 1981. Physiological and morphological criteria for alfalfa plant 
breeding: Salt tolerance of alfalfa. Uni. Wyoming Agric. Exp. Station Res. J., 87-93.

El-kholy, A.S., A.E. Hall and A.A. Mohsen. 1997. Heat and chilling tolerance during germination and heat tolerance during flowering are not associated in cowpea. Crop Sci. 37:456-463.

Falconer, D.S. and T.F.C. Mackay. 1996. Introduction to quantitative genetics. 4th ed. Longman Essay, England.

Galiba, C., Z. Nagi, T. Janda, K. Szente, Z. Csintalan. R. Tuberosa, P. Monneveux and M. Coumans. 1997. Heat stress-induced alterations iii the photosynthesis, membrane thermostability and biomass production of bread and durum wheat varieties. Acta Agron. Hungarica 45:1-15.

Ibrahim, A.M.H. and J.S. Quick. 2001a. Heritability of heat tolerance in winter and spring wheat. Crop Sci. 41:14011405.

Ibrahim, A.M.H. and J.S. Quick. 200lb. Genetic control of high temperature tolerance in wheat as measured by membrane thermal stability. Crop Sci. 41:1405-1407.

Iqbal, K., F.M. Azhar, I.A. Khan and Ehsan-Ullah, 2011. Variability for drought tolerance in cotton (Gossypium hirsutum) and its genetic basis. Int. J. Agric. Biol. 13: 61-66.

Irshad, M., I. Khaliq, A.S. Khan and A. Ali. 2012. Genetic studies for some agronomic traits in spring wheat under heat stress. Pak. J. Agric. Sci. 49: 11-20.

Ismail, A.M. and A.E. Hall. 1999. Reproductive-stage heat tolerance, leaf membrane thermostability and plant morphology in cowpea. Crop Sci. 39: 1762-1768.

Khan, A. I., I. A. Khan and H. A. Sadaqat. 2008. Heat tolerance is variable in cotton (Gossypium hirsutum L.) and can be exploited for breeding of better yielding cultivars under high temperature regimes. Pak. J. Bot. 40: 2053-2058.

Kohel, R.J. 1987. Seed oil content of glanded and glandless cottons. J. Amer. Oil Chem. Soc. 64:1337-1340.

Little, T.M. and F.J. Hills. 1978. Agricultural Experimentation: Design and Analysis. John Wiley \& Sons, Inc., New York USA.

Mackill, D.J., W.R. Coffrnan and J.N. Rutger. 1982. Pollen shedding and combining ability for high temperature tolerance in rice. Crop Sci. 22:730.

Malik, M.N., F. Chaudhry and M. Makhdum. 1999. Cell membrane thermostability as a measure of heat tolerance in cotton. Pak. J. Sci. End. Res. 42: 44-46.

Martineau, J.R., J.E. Specht, J.H. Williams and C.Y. Sullivan. 1979a. Temperature tolerance in soybean. I. Evaluation of temperature for assessing cellular membrane thermostability. Crop Sci. 19: 75-78.

Martineau, J.R., J.H. Williams and J.E. Specht. 1979b. Temperature tolerance in soybeans. II. Evaluation of segregating populations for membrane thermostability. Crop Sci. 19: 79-81.

Mather, K. and J.L. Jinks. 1982. Biometrical Genetics. 3rd ed. Chapman and Hail Ltd. London, UK.

Mutters, R.G. and A.E. Hall. 1992. Reproductive responses of cowpea to high temperature during different night periods. Crop Sci. 32: 202-206.

Noble, C.L., G.M., Holloran and D. W. West. 1984. Identification and selection for salt tolerance in lucerne (Medicago sativa L.). Aust. J. Agric. Res. 35: 239 -252.

Oosterhuis, D.M. 1999. Yield response to environmental extremes in cotton. In "Proceeding of the 1999 Cotton Research Meeting" (C.P. Dugger and D.A. Richter, Eds.), pp. 30-38. National Cotton Council of America, Memphis, TN.

Rahman, H., S.A., Malik and M. Saleem. 2004. Heat tolerance of upland cotton during the fruiting stage evaluated using cellular membrane thermo stability. Field Crops Res. 85: $149-158$
Rahman, S. and T.A. Malik. 2008. Genetic analysis of fibre traits in cotton. Int. J. Agric. Biol. 10: 209-212.

Randhawa, L.S., G.S. Chahal and T.H. Singh, 1986. Role of epistasis in the inheritance of yield and its components in upland cotton. Indian J. Agric. Sci. 56: 494-496.

Reddy, K.R., H.F. Hodges and J.M. McKinion. 1997a. A comparison of scenarios for the effects of global climate change on cotton growth and yield. Aust. J. Plant Physiol. 24: 707-713.

Reddy, V.R., D.N. Baker and H.F. Hodges. 1991a. Temperature effect on cotton canopy growth, photosynthesis and respiration. Agron. J. 83:699-704.

Rehman, H., S.A. Malik and M. Saleem. 2004. Heat tolerance of upland cotton during the fruiting stage evaluated using cellular membrane thermostability. Field Crop Res. 85: 149158.

Saranga, Y., A. Cahaner, D. Zamir, A. Marani and J. Rudich, 1992. Breeding tomatoes for salt tolerance: inheritance of salt tolerance and related traits in interspecific populations. Theor. Appl. Genet. 84: 390-396.

Saravanan, N.A., A. Gopalan and R. Sudhagar. 2003. Genetic analysis of quantitative characters in cotton (Gossypium spp.). Madras Agric. J. 90: 236-238.

Sarwar, M.K.S., M.Y., Ashraf, M. Rahman and Y. Zafar. 2012. Genetic variability in different biochemical traits and their relationship with yield and yield parameters of cotton cultivars grown under water stress conditions. Pak. J. Bot. 44: 515-520.

Shakoor, M.S., T.A., Malik, F.M., Azhar and M.F. Saleem. 2010. Genetics of agronomic and fiber traits in upland cotton under drought stress. Int. J. Agric. Biol. 12: 495-500.

Shanahan, J.F., I.B. Edwards, J.S. Quick and J.R. Fenwick. 1990. Membrane thermo stability and heat tolerance of spring wheat. Crop Sci. 30: 247-251.

Singh, R., R.P., Patel, R.P., Singh and Lalmani. 2000. An experimental study of hiss-triggered chorus emissions at low latitude. Earth Planets Space 52: 37-40.

Srinavasan, A., H. Takcda and T. Sanboku. 1996. Heal tolerance in food legumes as evaluated by cell membrane therniostability and chlorophyll fluorescence techniques. Euphytica 88: 35-45.

Steel, R.G.D., J.H. Torrie and D. Dickey.1997. Principles and Procedure of Statistics. A Biometrical Approach $3^{\text {rd }}$ Ed. McGraw Hill Book Co. Inc., New York.

Sullivan, C.Y. 1972. Mechanisms of Heat and Drought Resistance in Grain Sorghum and Methods of Measurement. In: N.G.P. Rao and L.R. House (Eds.), Sorghum in the Seventies. New Delhi, India: Oxford \& IBH Publishing Co., pp. 247-264.

Sullivan, C.Y. and W.M. Ross. 1979. Selecting for drought and heat resistance in grain sorghum. In: Mussel, H. and R. Staple (eds.). Stress Physiology in Crop Plants, John Viley \& Sons, NY.

Taha, M.A., M.N.A. Malik, F.L. Chaudhry and I. Makhdum. 1981. Heat induced sterility in cotton sown during early April in West Punjab. Exp. Agric. 17:189-194.

Trolinder, N.L. and X. Shang. 1991. In vitro selection and regeneration of cotton resistant to high temperature stress. Plant Cell Reports 10: 448-452.

Ulloa, M., 2006. Heritability and correlations of agronomic and fibre traits in an okra leaf upland cotton population. Crop Sci. 46: $1508-14$

Yoshida, S., T. Satake and D.J. Mackill. 1981. High Temperature Stress in Rice. Paper Series No. 67. International Rice Research Institute Research (IRRI), Manila, Philippines. 